Article

\title{
Exploring the Potential of a Gamified Approach to Reduce Energy Use and Carbon Emissions in the Household Sector
}

\author{
Marta Gangolells*(D), Miquel Casals (D, Marcel Macarulla (D) and Núria Forcada (D) \\ Group of Construction Research and Innovation (GRIC), Department of Project and Construction Engineering, \\ Universitat Politècnica de Catalunya, C/Colom, 11, Ed. TR5, 08222 Terrassa, Spain; \\ miquel.casals@upc.edu (M.C.); marcel.macarulla@upc.edu (M.M.); nuria.forcada@upc.edu (N.F.) \\ * Correspondence: marta.gangolells@upc.edu; Tel.: +34-937-398-947; Fax: +34-937-398-101
}

check for updates

Citation: Gangolells, M.; Casals, M.; Macarulla, M.; Forcada, N. Exploring the Potential of a Gamified Approach to Reduce Energy Use and Carbon Emissions in the Household Sector. Sustainability 2021, 13, 3380. https:// doi.org/10.3390/su13063380

Academic Editors: Raluca

Andreea Felseghi and Maria

Simona Raboaca

Received: 24 February 2021

Accepted: 16 March 2021

Published: 18 March 2021

Publisher's Note: MDPI stays neutral with regard to jurisdictional claims in published maps and institutional affiliations.

Copyright: (c) 2021 by the authors. Licensee MDPI, Basel, Switzerland. This article is an open access article distributed under the terms and conditions of the Creative Commons Attribution (CC BY) license (https:/ / creativecommons.org/licenses/by/ $4.0 /)$.

\begin{abstract}
This paper analyzes the impact of an innovative approach based on gamification to promote reduced energy consumption in social housing. The game was developed and validated under the auspices of the EU-funded project EnerGAware-Energy Game for Awareness of energy efficiency in social housing communities in an affordable housing pilot located in Plymouth (United Kingdom). The results showed that the future exploitation of the game holds important energy- and emissionssaving potential. Assuming that the game is distributed freely by European energy providers to their domestic end-users, the game was found to be able to save more than 48.9 secondary terawatt-hours per year $\left(\mathrm{TWh}_{\mathrm{s}}\right)$ and 18.8 million tons of $\mathrm{CO}_{2 \mathrm{e}}$ annually, contributing up to around $8 \%$ to the target set for the European buildings sector to keep global warming under $2{ }^{\circ} \mathrm{C}$. The results also showed that the game is highly feasible from the energy point of view, even when we consider the energy consumed upstream, due to its low cumulative energy demand and its potential for household energy reduction. The results of this research provide helpful information for private and public stakeholders, as they contribute to determining the sustainability of promoting energy saving through gaming.
\end{abstract}

Keywords: serious game; social housing; energy efficiency; saving potential; life cycle energy requirements; energy payback time

\section{Introduction}

According to the latest figures [1], the buildings sector (including residential and tertiary sector buildings) was responsible for $41.77 \%$ of the final energy consumption at EU level in 2017. "Lowering energy use in this sector is a key strategy for achieving ambitious medium- and long-term energy and climate targets in the EU and its individual countries" [2], as stated in the European Union's 2030 climate and energy policy framework [3]. Within this context, the European Commission "has recognized the potential role that Information and Communication Technologies (ICT) can play in improving the energy performance of buildings in several high-level policy documents" [4-9].

ICT solutions effectively support the operation of smart grids in the context of load management optimization, renewable energy integration, supply and demand balancing, network peak reduction, dynamic pricing and prosumer management. As stated by Jáñez et al. [8] at the building level, "ICT solutions are very helpful to verify whether the building and the systems behave as designed". ICT also allows for the monitoring of buildings' energy performance to make sure it does not change through the whole building lifetime, or to highlight the need for adopting corresponding actions. ICT also enable higher energy savings by operating building systems at the optimum level, while maintaining users' comfort level. Further ICT applications within the energy-saving context are energy information systems aimed at encouraging energy conservation behaviors. Smart meter deployment and metering data usage undoubtedly boost energy feedback interventions. Although the existing literature encompasses a variety of ICT-based case 
studies with proven energy savings, "their market-wide diffusion is still rare and lagging behind expectations" [10]. Many stakeholders, such as utilities, service providers, agencies and local governments, still do not know "which digital energy services for customers may help them to stay competitive and in line with policy targets" [10].

First of all, as recently stated by Bastida et al. [11], "a comprehensive research into the realistic potentials for new technologies to contribute to reduction in electricity usage is much needed". Apart from some commendable initiatives, the ICT-enabled emissions abatement potential to lower greenhouse gas emissions in the buildings sector still remains unexplored.

Secondly, concerns about the environmental consequences caused by manufacturing, operation and disposal of ICT devices have been raised [12-14]. Previous authors have explored the impacts of ICT use on both direct household electricity consumption and indirect energy consumption related to providing ICT devices and operating ICT infrastructure [15-18]. Other researchers devoted their attention to the impacts derived from the manufacturing and disposal of electrical and electronic equipment, "not only because of increasing trends in the consumption globally, but also due to the shorter product life span" [19].

Therefore, ICT-based energy-saving technologies hold a dual role as they reduce the environmental impact, thus enabling buildings' higher energy performance, but they might concomitantly increase adverse effects as a consequence of the higher resource consumption and disposal levels. As stated by Zhou et al. [14], "to seek synergy between large-scale ICT development and environment protection actions in the digital era, scholars, policymakers and practitioners need a better understanding of how ICT interact with the environment". Within the context, it is especially important to assess how much energy needs to be invested to save energy. Darby [20] stated that "home automation accounts for a small but growing proportion of overall electricity use: whether or not this is justified in terms of increased system efficiency is a question that urgently needs addressing". Few previous initiatives have explored the life cycle energy implications of ICT-based energy-saving technologies. To the author's knowledge, only Van Dam et al. [21], Louis et al. [22], Beucker et al. [23], Gangolells et al. [24], Louis and Pongrácz [25] and Scheepens and Vogtländer [26] have assessed the life cycle impact of building energy management systems, but no references were found within the field of serious game-based solutions for energy saving. On the other hand, some previous research initiatives, such as the one lead by Kern et al. [27], assessed the carbon footprint of software products over their life cycles, but none of them analyzed the life cycle environmental implications of serious games for domestic energy saving.

The research question arising in this context is: "What is the potential of innovative ICT approaches based on gamification to reduce energy use and carbon emissions in the household sector?" This research question is addressed through lessons learned with the game developed under the EU-funded Horizon 2020 project EnerGAware-Energy Game for Awareness of energy efficiency in social housing communities [28]. The specific objectives of this paper are to (i) investigate the potential of the developed serious game to decrease household energy usage and to contribute to carbon dioxide emission reduction targets and (ii) evaluate whether the direct energy saving achieved by the game is greater than the energy consumed during its manufacturing, assembly, use and maintenance phases. Following this introduction, Section 2 provides a short literature review on serious games for household energy efficiency and Section 3 briefly outlines the EnerGAware project and the serious game developed in there. Section 4 describes the methodology used in this research and Section 5 discusses the obtained results. Finally, conclusions and policy implications are detailed in Section 6.

\section{Literature Review}

Gamification for energy-related behavior change has recently become a hot research topic. Morganti et al. [29], Johnson et al. [30], Pasini et al. [31], AlSkaif et al. [32], Csoknyai 
et al. [33], Himeur et al. [34] and Chatzigeorgiou and Andreou [35] provide comprehensive systematic reviews covering relevant initiatives within the area. As concluded by Mulcahy et al. [36] and Chatzigeorgiou and Andreou [35], gamification strategies seem to offer promising results.

However, as recently recognized by Anderson et al. [37], a large number of initiatives have been validated with non-robust experimental tests under normal academic convention. Therefore, the results reported up until now require cautious interpretations. Common methodological limitations include a short duration of the intervention, small sample sizes and methodological problems (no baseline period, absence of control group, self-reported measurements and non-weather corrected energy-saving measures). In addition, although most of the existing approaches test behavioral intentions, few of them measure actual energy savings. As stated by Frederiks et al. [38], under these conditions, the benefits and return on investment of these interventions cannot be properly evaluated; therefore, it is hard to determine "whether it can be cost-effectively scaled to millions of consumers across the population".

To the authors knowledge, there is no previous literature examining the overall energysaving potential of gamification-based approaches nor its cost-effectiveness. This paper aims at covering this gap and to do so, it relies on the results obtained by EnerGAware project ( $€ 2$ million funded research project) during the deployment of the Energy Cat: The House of Tomorrow serious game in the UK social housing pilot, as this is the most recent and complicated serious game for household energy efficiency according to Chatzigeorgiou and Andreou [35]. Section 3 briefly describes the game and how it was developed, implemented and validated. More details about the EnerGAware project and the serious game, including game development, pilot implementation and results, are available from Casals et al. [39].

\section{The EnerGAware Project}

The EU-funded project EnerGAware-Energy Game for Awareness of energy efficiency in social housing communities [28] developed an innovative serious game, called Energy Cat: The House of Tomorrow [40], to promote reduced energy consumption and carbon emission reduction in social housing by increasing tenants' understanding and engagement in energy efficiency communities [39]. Table 1 summarizes its main game design elements.

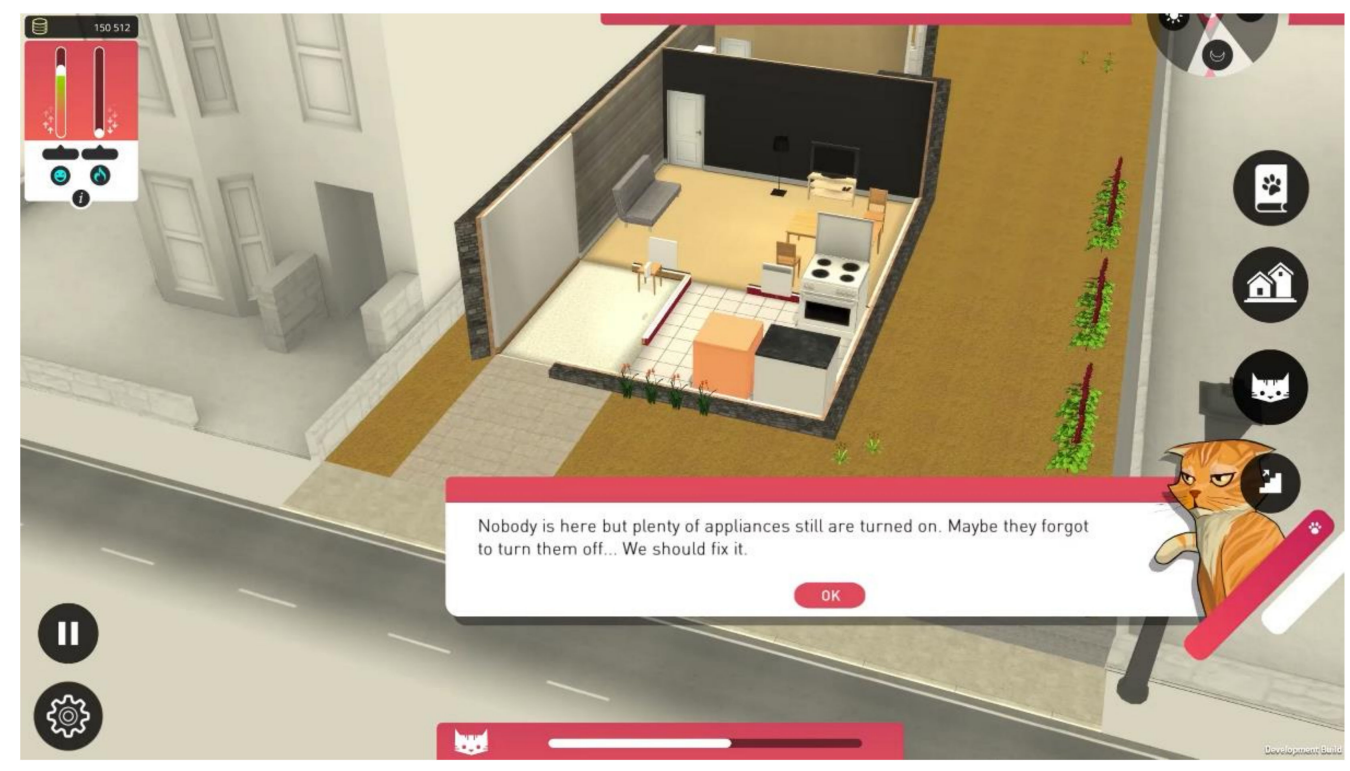

Figure 1. Screenshot of the game Energy Cat: The House of Tomorrow. Source: Energy Cat [40]. 
Table 1. Game design elements of Energy Cat: The House of Tomorrow [40].

\begin{tabular}{|c|c|}
\hline Challenge & $\begin{array}{l}\text { Users design and evolve their own virtual home (similar to } \\
\text { "The Sims" game). }\end{array}$ \\
\hline Educational Objective & $\begin{array}{l}\text { Users learn about potential and realistic energy savings due to } \\
\text { installing energy-saving measures and changing user behavior, } \\
\text { comparing and contrasting the financial cost of their actions but also } \\
\text { the resulting energy consumption and comfort (Figure 1). }\end{array}$ \\
\hline $\begin{array}{l}\text { Main Character and } \\
\text { Narrative Context }\end{array}$ & $\begin{array}{l}\text { The game protagonist is the "Energy Cat", who is controlled by the } \\
\text { player. The house is inhabited by humans (non-player characters) } \\
\text { with non-pro-environmental behaviors and the Energy Cat needs to } \\
\text { amend their actions (e.g., setting thermostats to a lower temperature } \\
\text { in the winter, reducing shower time, closing the windows when the } \\
\text { heating system is on, etc.). When building and evolving the house, } \\
\text { the player also needs to prioritize among several energy-saving } \\
\text { investments, such as replacing existing household appliances by } \\
\text { others with higher energy efficiency ratings, adding insulation to the } \\
\text { solid walls and implementing renewable energy technologies, among } \\
\text { others. Decisions must be taken on the basis of the initial investment } \\
\text { cost, related energy savings and achieved indoor comfort. }\end{array}$ \\
\hline Game Resources & $\begin{array}{l}\text { The game relies on three main resources: energy points, happiness } \\
\text { and money. Energy points represent the available energy to be } \\
\text { consumed over one day. Energy points diminish through the day at } \\
\text { the pace of the energy consumed by the house, estimated through } \\
\text { building performance simulation. Behavioral changes and upgrades } \\
\text { allow players to save energy points. Energy savings achieved } \\
\text { virtually unlock new game content (decorative items and } \\
\text { energy-saving upgrades). Human happiness mainly depends on } \\
\text { indoor comfort, but energy-efficient products and sustainable actions } \\
\text { also increase their happiness. Happy humans earn more money that } \\
\text { can then be used to buy items previously unlocked in the catalog, } \\
\text { including decorative stuff to customize the house, energy-efficient } \\
\text { appliances, resources needed to implement energy-saving measures } \\
\text { and renewable energy technologies. Too great of a reduction in the } \\
\text { happiness level to save energy points decreases the humans' } \\
\text { productivity and thus, daily monetary income. }\end{array}$ \\
\hline Feedback & $\begin{array}{l}\text { Real energy consumption feedback is displayed weekly using smart } \\
\text { meter data from the game user's home. Energy savings achieved in } \\
\text { reality (calculated in the users' real homes through smart meter data) } \\
\text { enable progression in the game. }\end{array}$ \\
\hline Social Sharing & $\begin{array}{l}\text { The game includes a platform for sharing data on achievements, } \\
\text { competing with each other and giving energy advice. }\end{array}$ \\
\hline
\end{tabular}

The game was implemented and validated in real-life conditions in a UK social housing pilot. Participants were recruited by sending a letter and a survey to 2772 social houses in Plymouth. In total, 537 tenants answered the survey and 137 of them agreed to participate in the monitoring stage of the project. However, some of these houses had to be discarded because the existing meters could not be monitored with the developed solution or because the tenants were no longer interested or not reachable after several attempts. The experimental design received full ethical approval from the Ethics Committee of the University of Plymouth and the EU Commission Services; therefore, personal data was collected and managed in compliance with fundamental ethical and legal principles.

Tenants participating in the pilot (around 100) were randomly assigned to the experimental or the control group using a pairing approach. After the assignment process and from the socio-economical perspective, no significant differences were found between the groups. The impact of the EnerGAware serious game intervention was assessed by comparing the energy consumption before and after the intervention. Other dependent variables, such as (i) energy consumption behavior and energy awareness, (ii) peak de- 
mand, (iii) social media activity and energy knowledge sharing and (iv) IT literacy, were also assessed. An ad hoc monitoring infrastructure was developed "to ensure maximum compatibility with pre-existing electricity and gas meter typologies" [41]. The baseline period (14 months) started once the real-time energy monitoring system was implemented in all the houses and finished when tenants in the experimental group were provided with an Android tablet so they could play the game. The reporting period (12 months) started once tenants received the tablet and finished when monitoring kits were removed and surveys were answered [41]. A control group approach was implemented to properly identify potential influencing effects other than the game. The independent variables used to identify unavoidable variations included (i) socio-economic status and heath, (ii) energy price, (iii) perceived physical comfort, (iv) usability and usefulness and (v) game interaction (e.g., energy price increases, lockdown periods, etc.).

Energy savings provided by the game were estimated by calculating the "average energy consumption reduction of houses in the experimental group during the reporting period in relation to the baseline" [41]. In order to take into account weather changes that may affect energy consumption profiles when comparing different periods of time, heating degree days (HDD) based at $15.5^{\circ} \mathrm{C}$ were calculated for both the baseline and the reporting periods. Cooling degree days (CDD) were discarded as houses in the pilot had no air conditioning systems. Table 2 summarizes the data regarding the baseline energy consumption and achieved savings.

Table 2. Energy savings provided by the Energy Cat game during the pilot experiment.

\begin{tabular}{ccc}
\hline & Electricity & Gas \\
\hline Baseline consumption $\left[\mathrm{kWh}_{\mathrm{s}} / \mathrm{day} \cdot\right.$ house] & 9.08 & 14.10 \\
\hline Saving $[\%]$ & $3.46 \%$ & $7.48 \%$ \\
\hline
\end{tabular}

\section{Methodology}

The methodology used to estimate the impacts of the game-based solution for household energy saving developed in the EnerGAware project is depicted in Figure 2.

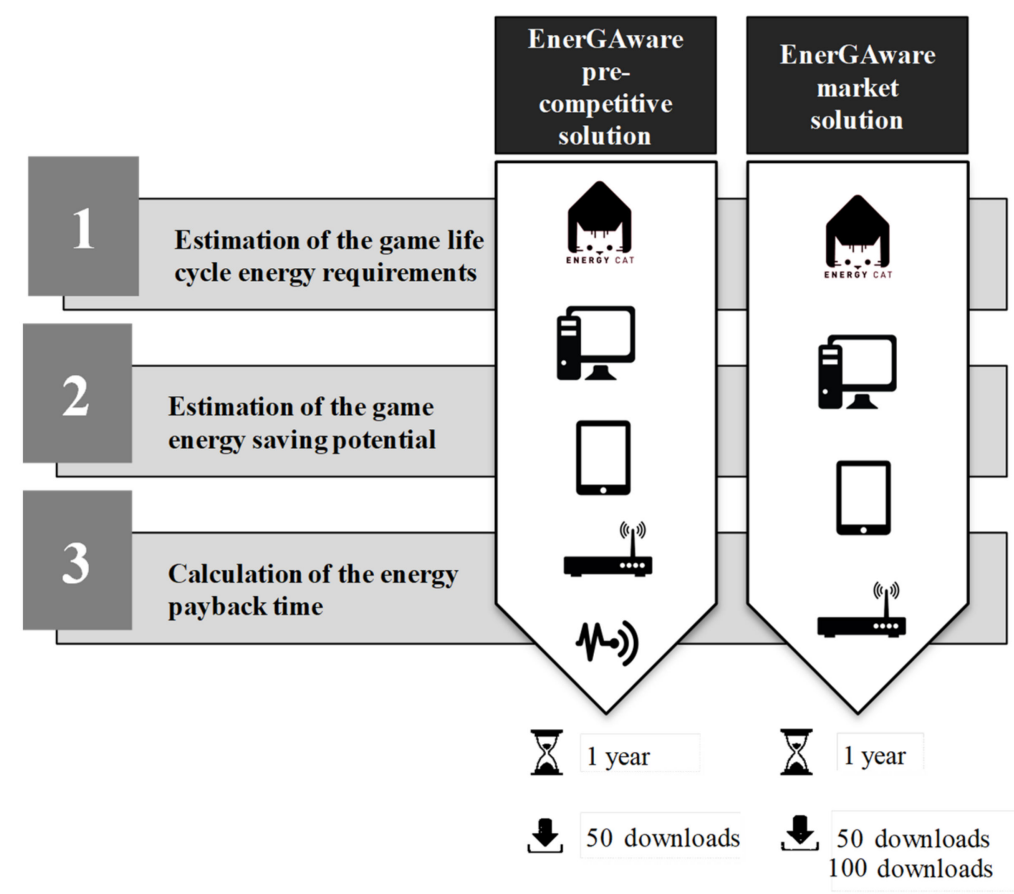

Figure 2. Methodology used to estimate the impacts of the game-based solution for household energy saving. Source: own elaboration. 
Two main scenarios are explored in this paper. The first scenario comprises the precompetitive solution and corresponds to the validation of the game in the pilot of the EnerGAware project [28]. The second scenario comprises the future exploitation of the game, considering that the game is downloaded and played by users on their own mobile devices.

The EnerGAware pre-competitive solution included the game "Energy Cat: The House of Tomorrow" [40], the server collecting the pilot households' game experience data and energy metering data, the tablet provided to the tenants on which they run the game and the energy monitoring system set up in the pilot houses (Figure 2). The main elements of the energy monitoring system were a data concentrator, an electricity meter, a gas meter and a server collecting data received from the energy monitoring infrastructure (Figure 3). For the sake of simplicity, the serious game was assumed to be played in 50 homes for one year, according to the duration of the project validation phase (Figure 2).

\section{ENERGY MONITORING SYSTEM}

\begin{tabular}{|c|c|c|c|c|c|c|c|c|c|c|}
\hline \multicolumn{8}{|c|}{ Data concentrator } & \multicolumn{2}{|c|}{$\begin{array}{c}\text { Electricity } \\
\text { meter }\end{array}$} & $\begin{array}{l}\text { Gas } \\
\text { meter }\end{array}$ \\
\hline \multirow[b]{2}{*}{$\begin{array}{c}\text { GPRS } \\
\text { antenna }\end{array}$} & \multicolumn{3}{|c|}{ Wireless receptors } & \multirow[b]{2}{*}{$\begin{array}{c}\text { Data } \\
\text { logger }\end{array}$} & \multirow[b]{2}{*}{$\begin{array}{l}\text { Power } \\
\text { supply }\end{array}$} & \multirow[b]{2}{*}{$\begin{array}{c}\text { Electrical } \\
\text { protections }\end{array}$} & \multirow[b]{2}{*}{ Cabinet } & \multirow[b]{2}{*}{$\begin{array}{l}\text { Pulse } \\
\text { reader }\end{array}$} & \multirow[b]{2}{*}{$\begin{array}{l}\text { Pulse } \\
\text { counter }\end{array}$} & \multirow[b]{2}{*}{$\begin{array}{c}\text { Energy } \\
\text { cam }\end{array}$} \\
\hline & $\begin{array}{c}\text { Mbus } \\
\text { antenna }\end{array}$ & $\begin{array}{c}\text { Mbus } \\
\text { antenna } \\
\text { connector }\end{array}$ & $\begin{array}{l}\text { Mbus } \\
\text { bridge }\end{array}$ & & & & & & & \\
\hline
\end{tabular}

Energy monitoring system server

Figure 3. Main components of the energy monitoring system. Source: own elaboration.

The EnerGAware market solution included the game "Energy Cat: The House of Tomorrow" [40], the server and the part of the tablet and the router needed to play the game (Figure 2). It is important to note that this scenario did not include a dedicated energy monitoring system, as in this case, the game was not linked to real energy consumption data. Outside the research project, both the number of downloads and the lifetime depend on many factors; thus, they are difficult to predict. In this research, the game was assumed to be downloaded 50 and 100 times. A one-year lifetime scenario was considered for ease of comparison (Figure 2).

The developed methodology included three main steps. The first step estimated the energy required by the game during the whole life cycle for both the EnerGAware precompetitive solution and the EnerGAware market solution (Section 4.1). The second step assessed the energy savings the game could provide in both scenarios (Section 4.2). Finally, the energy payback time was calculated considering the EnerGAware project scenario and the future exploitation of the Energy Cat serious game (Section 4.3).

\subsection{Estimation of the Game Life Cycle Energy Requirements}

The game energy requirements were estimated under a life cycle approach using the cumulative energy demand (CED) method [42]. The life cycle assessment (LCA) was conducted in accordance with the methodology outlined by ISO 14040 Environmental Management-Life Cycle Assessment-Principles and Framework [43] and ISO 14044 Environmental Management-Life Cycle Assessment-Requirements and Guidelines [44]. The system boundaries included the manufacturing (all steps, from raw material extraction to the assembly of all component devices), transport (from the production sites to the assembly site, located in Madrid, and then to the pilot homes in Plymouth), usage and maintenance of the system. The Ecoinvent v3.4 database [45] was chosen "because of its worldwide recognition as a scientifically reliable and constantly updated database" [46,47]. 
In any case, according to ISO 14044 guidelines [44], the data used were up to date and selected according to the corresponding geographic locations, as far as possible. The calculations were performed with SimaPRO 8.0 [48]. Table 3 summarizes the assumptions made in each life cycle stage for each subsystem.

Table 3. Key assumptions.

\begin{tabular}{|c|c|c|c|c|c|}
\hline & Game & Game Server & Tablet & Router & $\begin{array}{l}\text { Energy Monitoring } \\
\text { System }\end{array}$ \\
\hline Production & $\begin{array}{l}\text { Game production } \\
\text { involved 12,125 } \\
\text { computer hours. }\end{array}$ & $\begin{array}{l}\text { The device (computer } \\
\text { desktop without } \\
\text { screen) is identified } \\
\text { in the Ecoinvent } \\
\text { database. }\end{array}$ & $\begin{array}{l}\text { Components and } \\
\text { materials are } \\
\text { identified and } \\
\text { quantified according } \\
\text { to the tablet's } \\
\text { technical } \\
\text { specifications, direct } \\
\text { observation and } \\
\text { expert consultation. }\end{array}$ & $\begin{array}{l}\text { The device (router) is } \\
\text { identified in the } \\
\text { Ecoinvent database. }\end{array}$ & $\begin{array}{l}\text { Components and } \\
\text { materials are identified } \\
\text { and quantified according } \\
\text { to the technical } \\
\text { specifications of the pilot } \\
\text { deployment plan, direct } \\
\text { observation and expert } \\
\text { consultation. }\end{array}$ \\
\hline Transport & - & $\begin{array}{l}\text { Transport from the } \\
\text { manufacturing site to } \\
\text { the game developer } \\
\text { premises. }\end{array}$ & $\begin{array}{l}\text { Transport from the } \\
\text { production site to the } \\
\text { pilot site. }\end{array}$ & $\begin{array}{l}\text { Transport from the } \\
\text { production site to the } \\
\text { pilot site. }\end{array}$ & $\begin{array}{l}\text { Transport from the } \\
\text { manufacturing site to the } \\
\text { configuration site, and } \\
\text { then to the pilot site. }\end{array}$ \\
\hline Use & - & $\begin{array}{l}\text { The game server runs } \\
24 \mathrm{~h} \text { per day. }\end{array}$ & $\begin{array}{l}\text { According to data } \\
\text { gathered in the } \\
\text { pilot [49], tenants } \\
\text { played the game an } \\
\text { average of } \\
15 \text { min/week, for } \\
3 \text { months. }\end{array}$ & $\begin{array}{l}\text { The game is downloaded } \\
\text { once, and the process } \\
\text { lasts } 2 \text { min. } \\
\text { The router is assumed to } \\
\text { download meter readings } \\
3 \text { times a week for } \\
3 \text { months }{ }^{1} \text {. }\end{array}$ & $\begin{array}{l}\text { The energy monitoring } \\
\text { system works } 24 \mathrm{~h} \\
\text { per day. }\end{array}$ \\
\hline Maintenance & $\begin{array}{c}\text { Game improvements } \\
\text { involved } 1347 \\
\text { computer hours. }\end{array}$ & $\begin{array}{l}\text { The game server's } \\
\text { maintenance is } \\
\text { considered } \\
\text { negligible. }\end{array}$ & $\begin{array}{l}\text { The tablet's } \\
\text { maintenance is } \\
\text { considered } \\
\text { negligible. }\end{array}$ & $\begin{array}{c}\text { The router's maintenance } \\
\text { is considered negligible. } \\
\text { The router's energy } \\
\text { consumption when } \\
\text { downloading game } \\
\text { updates is neglected. }\end{array}$ & $\begin{array}{l}\text { Battery replacement for } \\
\text { the energy cam and the } \\
\text { wireless M-bus pulse } \\
\text { counter every } 12 \text { years. } \\
\text { Server maintenance is } \\
\text { considered negligible. }\end{array}$ \\
\hline
\end{tabular}

${ }^{1}$ Only for the EnerGAware pre-competitive solution scenario.

Within the EnerGAware pre-competitive solution scenario, the impact of the manufacturing and transport of ICT devices (including the tablet, the router and the monitoring system) was completely allocated to the analyzed system. As the game server hosts other games in addition to the game that was developed, only one-sixth of the impact of the game server was assigned to the EnerGAware pre-competitive solution scenario.

In the EnerGAware market scenario, the game was played on users' own devices (tablet and router). Therefore, production and transportation charges were allocated proportionally according to the time spent by the player on the Energy Cat serious game in relation to the total time the tablet was being used. Tenants played with the game for $15 \mathrm{~min}$ per week, on average, for 3 months. If it is assumed that a tablet is used for $90 \mathrm{~min}$ per day, the charges allocated to the system are $0.55 \%$ for one year, and $0.18 \%$ for three years. Similarly, the impact of the game server was shared with the six games hosted by the server.

\subsection{Estimation of the Game Energy-Saving Potential}

The potential effects of the Energy Cat serious game were estimated using the bottomup approach suggested in the EASME (Executive Agency for Small and Medium-sized Enterprises) guidelines [50] for the two main scenarios.

The first scenario concerns the effects the EnerGAware pre-competitive solution had in the Plymouth social housing pilot over one year, from game deployment to the end of the project. Therefore, the results obtained within the Plymouth social housing pilot project (Table 2) were used to quantify the energy savings achieved within the pilot experimenta- 
tion phase. Greenhouse gas emissions savings were estimated using UK primary energy factors [51] and UK emission factors [52].

The second scenario assumes that the Energy Cat serious game is promoted throughout Europe. In this case, overall electricity and gas consumption figures for the residential sector in each European member state [53] were used, since individualized household electricity and gas consumption figures were not available in the existing literature. The average energy savings obtained in the Plymouth pilot (Table 2) were used, but two different situations were devised. The first assumes that the Energy Cat game is freely distributed in App stores, and a penetration rate of $1 \%$ is considered according to the game developer expertise. The second situation assumes that the game is distributed by energy service providers to their clients. As this can be considered a guided context, a $40.91 \%$ penetration rate is assumed (the same as that in the social housing pilot). Calculations were made using the individualized EU member state's emission factors [52] and the average EU primary energy factor [54].

\subsection{Calculation of the Energy Payback Time}

Along the lines of Gangolells et al. [24], the energy payback time can be determined according to the following equation:

$$
E P B T=\frac{C E D}{E_{\text {saved }}}
$$

where $C E D$ is the life-cycle cumulative energy demand of the game or the energy consumed during all its life cycle stages, expressed in $\mathrm{kWh}_{\mathrm{p}}$, and $E_{\text {saved }}$ is the energy savings provided by the game, measured in $\mathrm{KWh}_{\mathrm{p}}$.

\section{Results and Discussion}

Obtained results are described and discussed in the following subsections.

\subsection{Estimation of the Life Cycle Energy Requirements}

The cumulative energy demand of the EnerGAware pre-competitive solution during the assembly, transport, use and maintenance phases was $147,350.73 \mathrm{kWh}_{\mathrm{p}}$ (Table 4). The initial embodied energy (energy consumed from the cradle to the pilot site) accounted for $84.57 \%$, whereas the operational energy (energy consumed during the use phase) was about $15.31 \%$. The recurring embodied energy (energy used during maintenance activities) represented only $0.13 \%$ of the total energy consumption (Table 4 ).

Table 4. Cumulative energy demand during the assembly, transport, use and maintenance phases.

\begin{tabular}{|c|c|c|c|c|c|c|}
\hline & \multirow{2}{*}{\multicolumn{2}{|c|}{ EnerGAware Pre-Competitive Solution }} & \multicolumn{4}{|c|}{ EnerGAware Market Solution } \\
\hline & & & \multicolumn{2}{|c|}{50 Downloads } & \multicolumn{2}{|c|}{100 Downloads } \\
\hline & {$\left[\mathrm{kWh}_{\mathrm{p}}\right]$} & [\%] & {$\left[\mathrm{kWh}_{\mathrm{p}}\right]$} & {$[\%]$} & {$\left[\mathrm{kWh}_{\mathrm{p}}\right]$} & [\%] \\
\hline $\begin{array}{c}\text { Initial } \\
\text { embodied energy }\end{array}$ & $124,607.18$ & $84.57 \%$ & 2008.79 & $54.83 \%$ & 2090.58 & $55.72 \%$ \\
\hline Operational energy & $22,556.47$ & $15.31 \%$ & 1470.71 & $40.14 \%$ & 1477.60 & $39.38 \%$ \\
\hline Recurring embodied energy & 187.07 & $0.13 \%$ & 184.03 & $5.02 \%$ & 184.03 & $4.90 \%$ \\
\hline Total & $147,350.72$ & $100.00 \%$ & 3663.52 & $100.00 \%$ & 3752.21 & $100.00 \%$ \\
\hline
\end{tabular}

The cumulative energy demand of the EnerGAware market scenario was found to range from $3663.52 \mathrm{kWh}_{\mathrm{p}}$ (50 downloads) to $3752.21 \mathrm{kWh}_{\mathrm{p}}$ (100 downloads) considering one year of useful life (Table 4). For 100 downloads, the operational energy represented $55.72 \%$ of the total electricity consumption, whereas the initial embodied energy was $39.39 \%$, and the recurring embodied energy amounted to only $4.90 \%$. Similar percentages 
were found when the system was analyzed for 50 downloads, because the energy consumed during the operational phase per download was very small. When the time frame was extended, the operational energy proportionally increased, but the initial and recurring embodied energies did not to change significantly.

As shown in Table 4, the initial embodied energy of the EnerGAware pre-competitive solution involved a cumulative energy demand of $124,607.18 \mathrm{kWh}_{\mathrm{p}}$, mostly attributable to the assembly $\left(115,281.91 \mathrm{kWh}_{\mathrm{p}}\right)$, and to a lesser extent, the transport $\left(9325.27 \mathrm{kWh}_{\mathrm{p}}\right)$. Figure 4 shows the energy breakdown of the EnerGAware pre-competitive solution during the assembly phase. The energy monitoring system dominated energy consumption $(87.47 \%)$. Electricity meters were responsible for consuming $65,134.08 \mathrm{kWh}_{\mathrm{p}}(64.59 \%$ of the energy consumption of the energy monitoring system), whereas data concentrators consumed $33,597.68 \mathrm{kWh}_{\mathrm{p}}$ (33.32\% of the energy), gas meters consumed $1298.77 \mathrm{kWh}_{\mathrm{p}}$ $(1.29 \%)$ and the energy monitoring system server consumed $811.46 \mathrm{kWh}_{\mathrm{p}}(0.80 \%)$. The Energy Cat game, the game server, the tablet and the router were responsible for the remaining $12.53 \%$ of the total energy consumption (Figure 4 ). In this case, the router subsystem accounted for $6.33 \%$ of the total energy consumption $\left(7298.68 \mathrm{kWh}_{\mathrm{p}}\right)$, whereas the tablet was responsible for $4.64 \%\left(5349.49 \mathrm{kWh}_{\mathrm{p}}\right)$ of the energy consumption, the game represented $1.44 \%$ of the energy consumption $\left(1656.50 \mathrm{kWh}_{\mathrm{p}}\right)$ and the game server was responsible for $0.12 \%$ of the energy consumption $\left(135.24 \mathrm{kWh}_{\mathrm{p}}\right)$.

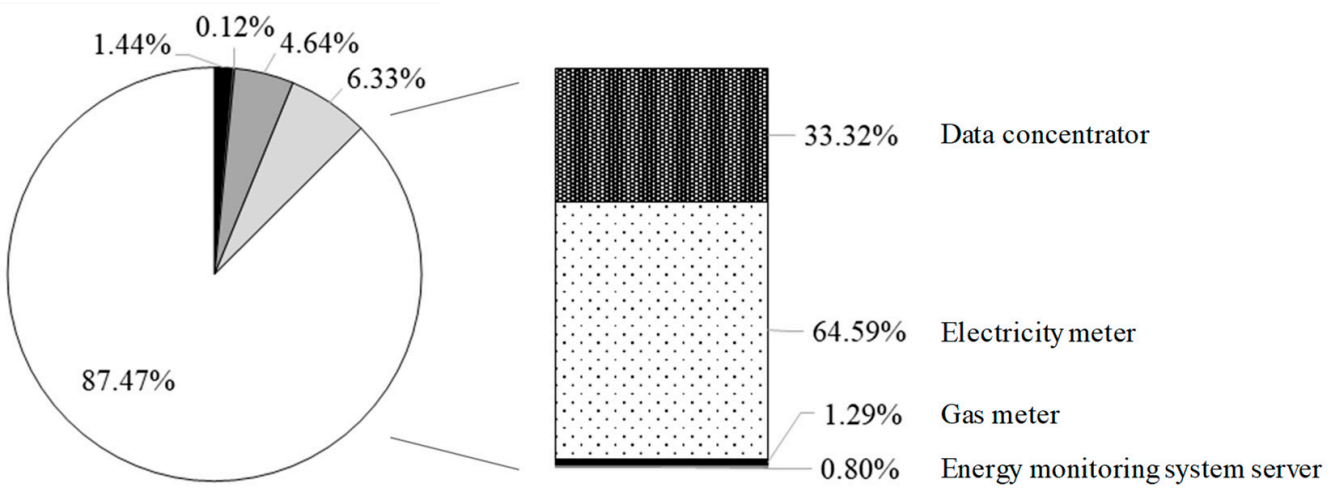

घEnergy Cat game $\square$ Game server $\square$ Tablet $\square$ Router $\quad \square$ Energy monitoring system

Figure 4. Cumulative energy demand during the assembly phase of the EnerGAware pre-competitive solution.

The cumulative energy demand related to the assembly of the market scenario was found to be much lower, ranging between $1861.05 \mathrm{kWh}_{\mathrm{p}}$ and $1930.36 \mathrm{kWh}_{\mathrm{p}}$ when a oneyear lifespan was considered, depending of the number of downloads (Table 5). In this case, the energy consumption was clearly dominated by the serious game itself $\left(1656.50 \mathrm{kWh}_{\mathrm{p}}\right)$ and ranged from $85.81 \%$ (100 downloads) to $89.01 \%$ (50 downloads). The game server consumed $135.24 \mathrm{kWh}_{\mathrm{p}}$, which represented between $7.01 \%$ (100 downloads) and 7.27\% (50 downloads). The energy consumption of the router ranged from $39.99 \mathrm{kWh}_{\mathrm{p}}(2.15 \%)$ to $79.99 \mathrm{kWh}_{\mathrm{p}}(4.14 \%)$ and the energy consumption of the tablet ranged from $29.31 \mathrm{kWh}_{\mathrm{p}}$ $(1.57 \%)$ to $58.62 \mathrm{kWh}_{\mathrm{p}}(3.04 \%)$ (Table 5). Increasing the number of downloads decreased the influence of the game and the game server in favor of the tablet and the router. 
Table 5. Cumulative energy demand during the assembly phase of the EnerGAware market solution.

\begin{tabular}{ccccc}
\hline & \multicolumn{2}{c}{50 Downloads } & \multicolumn{2}{c}{ 100 Downloads } \\
\cline { 2 - 5 } & {$[\mathbf{k W h} \mathbf{p}]$} & {$[\%]$} & {$[\mathbf{k W h} \mathbf{p}$} & {$[\%]$} \\
\hline Energy Cat game & 1656.50 & $89.01 \%$ & 1656.50 & $85.81 \%$ \\
\hline Game server & 135.24 & $7.27 \%$ & 135.24 & $7.01 \%$ \\
\hline Tablet & 29.31 & $1.57 \%$ & 58.62 & $3.04 \%$ \\
\hline Router & 39.99 & $2.15 \%$ & 79.99 & $4.14 \%$ \\
\hline Total & $\mathbf{1 8 6 1 . 0 5}$ & $\mathbf{1 0 0 . 0 0} \%$ & $\mathbf{1 9 3 0 . 3 6}$ & $\mathbf{1 0 0 . 0 0 \%}$ \\
\hline
\end{tabular}

\subsection{Estimation of the Energy-Saving Potential}

The EnerGAware pre-competitive solution was found to have a limited effect, with an estimated saving of $0.009 \mathrm{GWh}_{\mathrm{s}}$ and 4 tons of $\mathrm{CO}_{2 \mathrm{e}}$ annually (Table 6). However, the market scenario showed a much higher energy- and emissions-saving potential. Country specific estimations related to the energy- and emissions-saving potential of the game were found to be highly variable depending on the existing baseline energy consumption and the game penetration rate (Table A1 in Appendix A). Assuming that the game is freely distributed across Europe, energy savings were found to amount to 1.19 secondary terawatt-hours per year $\left(\mathrm{TWh}_{\mathrm{s}}\right.$ /year), providing an annual reduction of 460,527 tons of $\mathrm{CO}_{2 \mathrm{e}}$ (Table 6). When it was assumed that the game is distributed under the auspices of energy service providers, savings were found to amount to over $48.9 \mathrm{TWh}_{\mathrm{s}}\left(\right.$ or $65.1 \mathrm{TWh}_{\mathrm{p}}$ ) and 18.8 million tons of $\mathrm{CO}_{2 \mathrm{e}}$ per year (Table 6) in Europe.

Table 6. Potential impacts of the Energy Cat serious game.

\begin{tabular}{|c|c|c|c|}
\hline & $\begin{array}{c}\text { Energy Saving } \\
\left(\text { GWh }_{\mathrm{p}} / \text { Year }\right)\end{array}$ & $\begin{array}{c}\text { Energy Saving } \\
\left(G W h_{s} / \text { Year }\right)\end{array}$ & $\begin{array}{c}\text { Emissions Saving } \\
\left(\mathrm{tCO}_{2 \mathrm{e}} / \text { Year }\right)\end{array}$ \\
\hline \multicolumn{4}{|c|}{ Scenario 1: EnerGAware pre-competitive solution } \\
\hline Pilot tenants & 0.013 & 0.009 & 4 \\
\hline \multicolumn{4}{|c|}{ Scenario 2: EnerGAware market solution } \\
\hline $\begin{array}{l}1 \% \text { penetration rate in the EU } \\
\text { housing stock }\end{array}$ & 1590 & 1195 & 460,527 \\
\hline $\begin{array}{l}40.91 \% \text { penetration rate in the } \\
\text { EU housing stock }\end{array}$ & 65,063 & 48,869 & $18,839,744$ \\
\hline
\end{tabular}

Along the lines of the Paris Agreement objectives, the 2030 EU Climate and Energy Framework [3] set a "greenhouse gas emissions reduction target of $40 \%$ in relation to 1990 levels by 2030". To achieve the target, non-emission trading system sectors (such as the buildings sector) need to cut emissions by 30\% compared to 2005. Taking into account that the buildings sector was responsible for 790 million tons of $\mathrm{CO}_{2}$ in 2005 [55], buildings are asked to reduce 237 million tons of $\mathrm{CO}_{2}$ by 2030 . According to the obtained results, the EnerGAware game-based solution for household energy saving could contribute around $8 \%$ to the target set for the buildings sector to keep warming under $2{ }^{\circ} \mathrm{C}$, if the game is distributed by energy service providers to all European households. These results compare well with those reported by Bastida et al. [11], quantifying the potential for ICT-based solutions to induce energy-saving behavior changes.

\subsection{Calculation of the Energy Payback Time}

The length of time the EnerGAware pre-competitive solution (scenario 1) must operate before it recovers the energy invested throughout its lifetime (Table 7) was found to be higher than the duration of the research project itself. 
Table 7. Energy payback time, in years, considering the full life cycle of the Energy Cat serious game.

\begin{tabular}{lc}
\hline & Energy Payback Time (Years) \\
\hline Scenario 1: EnerGAware pre-competitive solution & \\
$\quad$ Pilot tenants & 4.18 \\
Scenario 2: EnerGAware market solution & 0.10 \\
50 downloads & 0.05 \\
100 downloads &
\end{tabular}

The time required for the EnerGAware market solution (scenario 2) to save the amount of energy consumed during its production, transport, use and maintenance was found to be 0.10 years ( 37.94 days), if the game was downloaded 50 times. However, when the number of downloads increases, the energy payback time decreases sharply. When just 100 downloads were considered, the energy payback time was found to be 0.05 years (19.43 days). This means that under these conditions, the system pays back 18.79 times the energy invested in it. The energy payback time substantially decreased when a higher useful life was considered, mainly because the savings increased proportionally.

In the EnerGAware market scenario, the break-even point (number of downloads making the game viable from an energy perspective) was estimated to be 5.1 downloads (Figure 5). In other words, the energy invested in the game is compensated effectively enrolling just six houses. Although the operational impact depends on the electricity mix of the country where the game is played, after any significant number of downloads and any significant lifespan, the energy savings provided by the game during the operational phase go far beyond the energy consumed by the game during the raw materials acquisition, manufacturing, transportation, operation and maintenance phases; this is mainly because the game relies on pre-existing devices and achieved savings are replicated as time passes and the number of players is boosted.

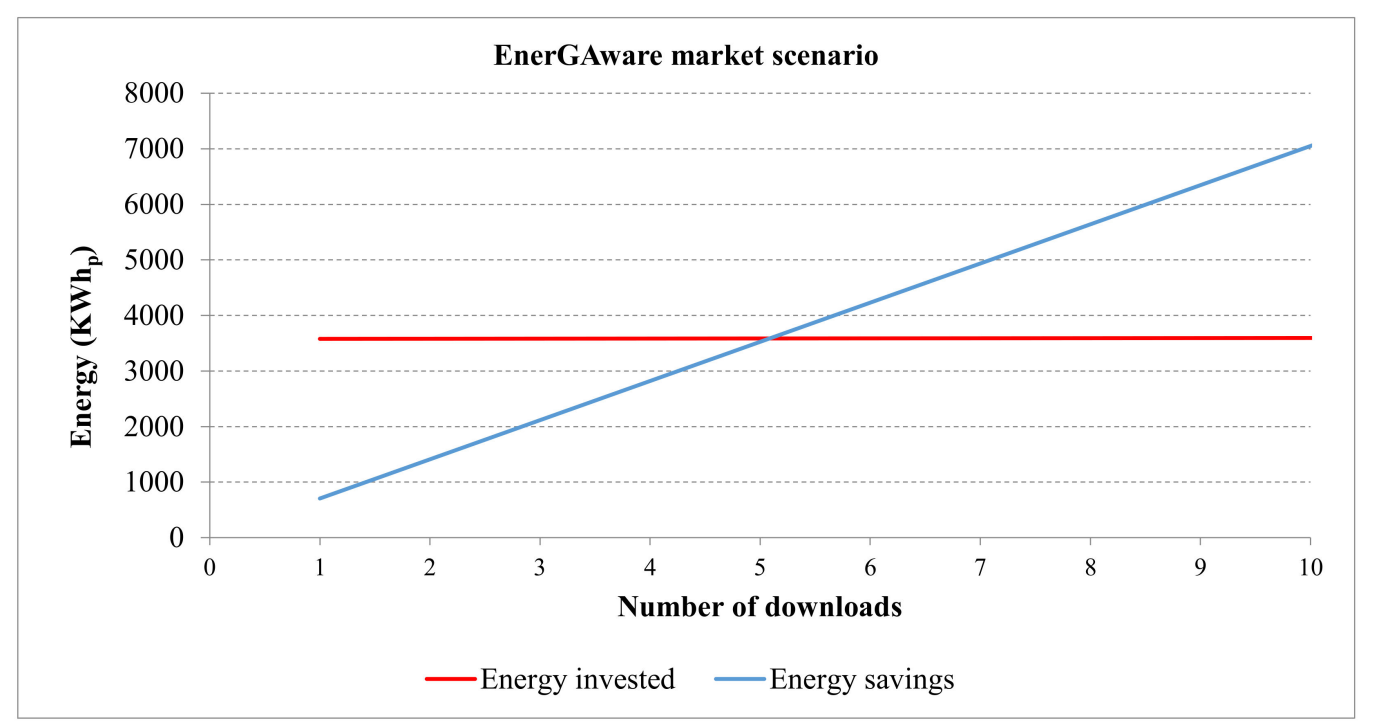

Figure 5. Energy cost-benefit opportunity of the EnerGAware market scenario. Source: own elaboration.

\section{Conclusions}

This paper investigated the impacts of an innovative game-based solution for household energy savings, developed within the EU-funded Horizon 2020 EnerGAware projectEnergy Game for Awareness of energy efficiency in social housing communities [28]. For the purpose of this research, two main scenarios were explored: the pre-competitive solution developed within the research project and the market solution, based on the future exploitation of the game. 
The game energy requirements were estimated under a life cycle approach with SimaPRO 8.0 [48] using the cumulative energy demand method [42] and the information contained within the Ecoinvent V3.4 database [45]. The cumulative energy demand amounted to $147,350.73 \mathrm{kWh}_{\mathrm{p}}$ for the EnerGAware pre-competitive solution. The market solution involved a much lower energy consumption, between $3663.52 \mathrm{kWh}_{\mathrm{p}}$ (50 downloads) and $3752.21 \mathrm{kWh}_{\mathrm{p}}$ (100 downloads), mainly because it relies on existing infrastructure. In both cases, most of the energy was found to be consumed during the initial phases, including the extraction of raw materials, manufacturing and transportation to the pilot site. In the pre-competitive scenario, the embodied energy represented $84.57 \%$ of the life cycle energy requirements. This percentage was found to be lower $(54.83 \%)$ for the market solution. When assuming higher lifespans, the operational energy was found to proportionally increase.

The EnerGAware pre-competitive solution showed a limited effect, with an estimated saving of $0.009 \mathrm{GWh}_{\mathrm{s}}$ and 4 tons of $\mathrm{CO}_{2 \mathrm{e}}$ per year. The market solution offered considerable potential for energy savings, especially if the EnerGAware game-based solution for household energy saving is distributed freely by energy providers to energy customers as part of the European smart meter roll-out. In this case, the game was estimated to be able to save $48.9 \mathrm{TWh}_{\mathrm{s}} /$ year and to contribute around $8 \%$ to the emissions reduction target set for the European buildings sector to meet the Paris Agreement and keep warming under $2{ }^{\circ} \mathrm{C}$.

When focusing on the amount of energy we need to spend to save the equivalent amount of energy, the results showed that the pre-competitive result is not feasible from an energy perspective. However, when we consider the Energy Cat game running on users' own tablets without the need for a dedicated energy management system, the break-even point is 5.1 downloads, and even lower when we consider higher lifespans. Assuming 100 downloads, the life cycle energy payback time is 19.43 days. This means that the game provides net energy savings for the remaining 345.57 days of the year. In addition, the energy payback time sharply decreased when longer periods of useful life were considered. Specifically, 100 downloads of the game were found to pay back 18.79 times the energy invested in them in one year.

Obtained results may be affected by several factors. The most important is the considered lifespan (understood as the length of time of the energy-saving effects produced by the game), as this can be highly variable and difficult to predict. In fact, there is high uncertainty about how household savings evolve in the long term (i.e., one and three years), as this has not been researched to date. For the purpose of this research, climate variables were also assumed to remain constant, but they can have a significant impact on the household energy consumption baselines. In addition, savings over such a period may be difficult to estimate and to assign to a specific intervention related to behavior change or increased awareness. Rapid technological development may also be a source of variability, because of the impact it may have on the estimation of the cumulative energy demand of the manufacturing, assembly and transport phases. Changes in the electricity mix during the assumed lifespan may also have a considerable impact on the obtained results.

Future research should focus on including the end-of-life phase, as this could lead to a better approximation of the game life cycle energy requirements. In order to model the environmental impact related to the end-of-life processing of ICT-related products, improved life cycle inventories are needed as well as a better characterization of e-waste management models.

Nevertheless, considering the obtained results, it can be concluded that game-based approaches for household energy saving are highly competitive in energy terms. Similar to renewable energy options, the association of energy payback time values with the choice of ICT energy-saving technology may have considerable policy implications for many stakeholders, such as energy utilities, energy service providers, housing agencies and policymakers. 
Author Contributions: Conceptualization, M.G.; Data curation, M.M.; Formal analysis, M.M.; Funding acquisition, M.C.; Investigation, N.F.; Methodology, M.G.; Project administration, M.C.; Resources, M.C.; Software, M.G.; Supervision, M.C.; Validation, M.G. and M.C.; Visualization, M.G.; Writingoriginal draft, M.G.; Writing-review and editing, M.G. All authors have read and agreed to the published version of the manuscript.

Funding: This research was funded by the European Union's Horizon 2020 research and innovation programme through the EnerGAware project-Energy Game for Awareness of energy efficiency in social housing communities, grant number $(649673,2015)$.

Institutional Review Board Statement: The study was conducted according to the guidelines of the Declaration of Helsinki and approved by the Ethics Committee of University of Plymouth (26 Febuary 2015).

Informed Consent Statement: Informed consent was obtained from all subjects involved in the study.

Data Availability Statement: Data available on request.

Conflicts of Interest: The authors declare no conflict of interest. 


\section{Appendix A}

Table A1. Estimated impact of the Energy Cat serious game in the European Union.

\begin{tabular}{|c|c|c|c|c|c|c|c|c|c|c|c|}
\hline & \multirow{2}{*}{\multicolumn{3}{|c|}{$\begin{array}{l}\text { Energy Consumption } \\
\quad\left(\mathrm{GWh}_{\mathrm{s}} / \text { Year) }\right.\end{array}$}} & \multicolumn{4}{|c|}{$1.00 \%$ Game Penetration Rate } & \multicolumn{4}{|c|}{ 40.91\% Game Penetration Rate } \\
\hline & & & & \multicolumn{3}{|c|}{ Energy Saving $\left(\mathrm{GWh}_{\mathrm{s}} /\right.$ Year $)$} & \multirow{2}{*}{$\begin{array}{c}\text { Emissions Saving } \\
\left(\mathrm{tCO}_{2 \mathrm{e}} / \text { Year }\right)\end{array}$} & \multicolumn{3}{|c|}{ Energy Saving $\left(\mathrm{GWh}_{\mathrm{s}} /\right.$ Year) } & \multirow{2}{*}{$\begin{array}{l}\text { Emissions Saving } \\
\quad\left(\mathrm{tCO}_{2 \mathrm{e}} / \text { Year }\right)\end{array}$} \\
\hline & Electricity & Gas & Total & Electricity & Gas & Total & & Electricity & Gas & Total & \\
\hline Austria & $17,812.51$ & $14,025.78$ & $31,838.29$ & 6.16 & 10.49 & 16.65 & 4902.94 & 252.13 & 429.19 & 681.32 & $200,574.77$ \\
\hline Belgium & $18,847.58$ & $39,825.77$ & $58,673.35$ & 6.52 & 29.79 & 36.31 & $10,668.41$ & 266.78 & 1218.67 & 1485.45 & $436,435.01$ \\
\hline Bulgaria & $10,733.33$ & 685.01 & $11,418.33$ & 3.71 & 0.51 & 4.23 & 6229.45 & 151.93 & 20.96 & 172.89 & $254,841.05$ \\
\hline Croatia & 6127.85 & 5418.42 & $11,546.26$ & 2.12 & 4.05 & 6.17 & 2220.26 & 86.74 & 165.80 & 252.54 & $90,828.82$ \\
\hline Cyprus & 1585.17 & $n / a$ & 1585.17 & 0.55 & $n / a$ & 0.55 & 953.24 & 22.44 & $n / a$ & 22.44 & $38,996.11$ \\
\hline Czech Republic & $14,935.25$ & $23,186.73$ & $38,121.98$ & 5.17 & 17.34 & 22.51 & $13,611.76$ & 211.40 & 709.51 & 920.92 & $556,844.72$ \\
\hline Denmark & $10,296.04$ & 7235.02 & $17,531.06$ & 3.56 & 5.41 & 8.97 & 4473.83 & 145.74 & 221.39 & 367.13 & $183,020.24$ \\
\hline Estonia & 1913.14 & 673.38 & 2586.51 & 0.66 & 0.50 & 1.17 & 1208.20 & 27.08 & 20.61 & 47.68 & $49,426.31$ \\
\hline Finland & $22,514.52$ & 311.68 & $22,826.20$ & 7.79 & 0.23 & 8.02 & 3356.04 & 318.68 & 9.54 & 328.22 & $137,292.74$ \\
\hline France & $159,396.13$ & $140,284.55$ & $299,680.68$ & 55.15 & 104.93 & 160.08 & $30,065.30$ & 2256.18 & 4292.71 & 6548.89 & $1,229,944.10$ \\
\hline Germany & $127,599.71$ & $256,935.78$ & $384,535.48$ & 44.15 & 192.19 & 236.34 & $98,144.54$ & 1806.12 & 7862.23 & 9668.35 & $4,015,003.93$ \\
\hline Greece & $19,996.62$ & 3827.43 & $23,824.06$ & 6.92 & 2.86 & 9.78 & $16,232.96$ & 283.04 & 117.12 & 400.16 & $664,075.76$ \\
\hline Ireland & 7873.51 & 6533.73 & $14,407.24$ & 2.72 & 4.89 & 7.61 & 5013.70 & 111.45 & 199.93 & 311.38 & $205,105.99$ \\
\hline Italy & $64,303.43$ & $198,843.93$ & $263,147.36$ & 22.25 & 148.74 & 170.98 & $54,640.73$ & 910.19 & 6084.62 & 6994.81 & $2,235,302.61$ \\
\hline Latvia & 1793.35 & 1237.43 & 3030.78 & 0.62 & 0.93 & 1.55 & 350.95 & 25.38 & 37.87 & 63.25 & $14,357.00$ \\
\hline Lithuania & 2774.92 & 1692.17 & 4467.08 & 0.96 & 1.27 & 2.23 & 589.63 & 39.28 & 51.78 & 91.06 & $24,121.18$ \\
\hline Luxembourg & 878.07 & 2573.72 & 3451.78 & 0.30 & 1.93 & 2.23 & 679.49 & 12.43 & 78.76 & 91.18 & $27,797.39$ \\
\hline Malta & 665.24 & $n / a$ & 665.24 & 0.23 & $n / a$ & 0.23 & 484.28 & 9.42 & $n / a$ & 9.42 & $19,811.50$ \\
\hline Netherlands & $22,654.08$ & $82,562.53$ & $105,216.61$ & 7.84 & 61.76 & 69.60 & $21,145.01$ & 320.66 & 2526.41 & 2847.07 & $865,023.12$ \\
\hline Poland & $28,908.69$ & $40,318.88$ & $69,227.58$ & 10.00 & 30.16 & 40.16 & $30,171.32$ & 409.19 & 1233.76 & 1642.95 & $1,234,281.17$ \\
\hline
\end{tabular}


Table A1. Cont.

\begin{tabular}{|c|c|c|c|c|c|c|c|c|c|c|c|}
\hline & \multirow{2}{*}{\multicolumn{3}{|c|}{$\begin{array}{l}\text { Energy Consumption } \\
\quad \text { (GWh }_{s} / \text { Year) }\end{array}$}} & \multicolumn{4}{|c|}{$1.00 \%$ Game Penetration Rate } & \multicolumn{4}{|c|}{ 40.91\% Game Penetration Rate } \\
\hline & & & & \multicolumn{3}{|c|}{ Energy Saving $\left(\mathrm{GWh}_{\mathrm{s}} /\right.$ Year) } & \multirow{2}{*}{$\begin{array}{l}\text { Emissions Saving } \\
\quad\left(\mathrm{tCO}_{2 \mathrm{e}} / \text { Year }\right)\end{array}$} & \multicolumn{3}{|c|}{ Energy Saving $\left(\mathrm{GWh}_{\mathrm{s}} /\right.$ Year) } & \multirow{2}{*}{$\begin{array}{c}\text { Emissions Saving } \\
\quad\left(\mathrm{tCO}_{2 \mathrm{e}} / \text { Year }\right)\end{array}$} \\
\hline & Electricity & Gas & Total & Electricity & Gas & Total & & Electricity & Gas & Total & \\
\hline Portugal & $13,089.57$ & 2924.95 & $16,014.51$ & 4.53 & 2.19 & 6.72 & 3768.01 & 185.28 & 89.50 & 274.78 & $154,145.67$ \\
\hline Romania & $12,067.29$ & $26,605.95$ & $38,673.24$ & 4.18 & 19.90 & 24.08 & $10,167.23$ & 170.81 & 814.14 & 984.95 & $415,932.12$ \\
\hline Slovakia & 5097.43 & $12,419.68$ & $17,517.11$ & 1.76 & 9.29 & 11.05 & 2961.47 & 72.15 & 380.04 & 452.19 & $121,150.97$ \\
\hline Slovenia & 3259.89 & 1337.45 & 4597.34 & 1.13 & 1.00 & 2.13 & 1540.65 & 46.14 & 40.93 & 87.07 & $63,026.54$ \\
\hline Sweden & $44,518.48$ & 380.30 & $44,898.78$ & 15.40 & 0.28 & 15.69 & 834.93 & 630.14 & 11.64 & 641.78 & $34,156.20$ \\
\hline United Kingdom & $107,970.59$ & $280,237.64$ & $388,208.24$ & 37.36 & 209.62 & 246.98 & $87,394.33$ & 1528.27 & 8575.27 & $10,103.55$ & $3,575,222.65$ \\
\hline EU-28 & $808,214.06$ & $1,223,182.92$ & $2,031,396.98$ & 279.64 & 914.94 & 1194.58 & $460,527.08$ & $11,439.90$ & $37,429.40$ & $48,869.30$ & $18,839,744.20$ \\
\hline
\end{tabular}




\section{References}

1. European Commission. EU Energy in Figures: Statistical Pocketbook. 2019. Available online: https://www.euneighbours.eu/en/ east/stay-informed/publications/eu-energy-figures-statistical-pocketbook-2019 (accessed on 26 March 2020).

2. Olsthoorm, M.; Schleich, J.; Faure, C. Exploring the diffusion of low-energy houses: An empirical study in the European Union. Energy Policy 2019, 129, 1382-1393. [CrossRef]

3. European Commission. Communication from the Commission to the European Parliament, the Council, the European Economic and Social Committee and the Committee of the Regions. A policy framework for climate and energy in the period from 2020 to 2030. 2014. Available online: https:/ / eur-lex.europa.eu/legal-content/EN/TXT/?uri=CELEX:52014DC0015 (accessed on 29 January 2021).

4. European Commission. Communication from the Commission to the European Parliament, the Council, the European Economic and Social Committee and the Committee of the Regions. Addressing the Challenge of Energy Efficiency through Information and Communication Technologies. 2008. Available online: http://ec.europa.eu/information_society/activities/sustainable_ growth/docs/com_2008_241_all_lang/com_2008_241_1_en.pdf (accessed on 18 October 2020).

5. European Commission. Communication from the Commission to the European Parliament, the Council, the European Economic and Social Committee and the Committee of the Regions on Mobilising Information and Communication Technologies to Facilitate the Transition to an Energy-Efficient, Low-Carbon Economy. 2009. Available online: https://eur-lex.europa.eu/legalcontent/EN/TXT/PDF/?uri=CELEX:52009SC0269\&from=ES (accessed on 18 October 2020).

6. European Commission. Communication from the Commission to the European Parliament, the Council, the European Economic and Social Committee and the Committee of the Regions. A Digital Agenda for Europe. 2010. Available online: https: / / eur-lex.europa.eu/legal-content/EN/TXT/PDF/?uri=CELEX:52010DC0245R(01)\&from=EN (accessed on 18 October 2020).

7. European Commission. Clean Energy for All Europeans. 2016. Available online: https://eur-lex.europa.eu/resource.html?uri= cellar:fa6ea15b-b7b0-11e6-9e3c-01aa75ed71a1.0001.02/DOC_1\&format=PDF (accessed on 18 October 2020).

8. Jáñez, A.; Profaizer, P.; Herrando, M.; Andérez, M.; Zabalza, I. Information and Communications Technologies (ICTs) for energy efficiency in buildings: Review and analysis of results from EU pilot projects. Energy Build. 2016, 127, 128-137. [CrossRef]

9. Europe Commission. Directive (EU) 2018/844 of the European Parliament and of the Council of 30 May 2018 Amending Directive 2010/31/EU on the Energy Performance of Buildings and Directive 2012/27/EU on Energy Efficiency. 2018. Available online: https:/ / eur-lex.europa.eu/legal-content/EN/TXT/PDF/?uri=CELEX:32018L0844\&from=EN (accessed on 18 October 2020).

10. Goldbach, K.; Rotaru, A.M.; Reichert, S.; Stiff, G.; Gölz, S. Which digital energy services improve energy efficiency? A multi-criteria investigation with European experts. Energy Policy 2018, 115, 239-248. [CrossRef]

11. Bastida, L.; Cohen, J.J.; Kollmann, A.; Moya, A.; Reichl, J. Exploring the role of ICT on household behavioural energy efficiency to mitigate global warming. Renew. Sustain. Energy Rev. 2019, 103, 455-462. [CrossRef]

12. Salahuddin, M.; Alam, K.; Ozturk, I. The effects of Internet usage and economic growth on $\mathrm{CO}_{2}$ emissions in OECD countries: A panel investigation. Renew. Sustain. Energy Rev. 2016, 62, 1226-1235. [CrossRef]

13. Danish, K. Effects of information and communication technology and real income on $\mathrm{CO}_{2}$ emissions: The experience of countries along Belt and Road. Telemat. Inform. 2019, 45, 101300. [CrossRef]

14. Zhou, X.; Zhou, D.; Wang, Q.; Su, B. How information and communication technology drives carbon emissions: A sector-level analysis for China. Energy Econ. 2019, 81, 380-392. [CrossRef]

15. Røpke, I.; Christensen, T.H.; Jensen, J.O. Information and communication technologies-A new round of household electrification. Energy Policy 2010, 38, 764-1773. [CrossRef]

16. Sadorsky, P. Information communication technology and electricity consumption in emerging economies. Energy Policy 2012, 48, 130-136. [CrossRef]

17. Sanquist, T.F.; Orr, H.; Shui, B.; Bittner, A.C. Lifestyle factors in U.S. residential electricity consumption. Energy Policy 2012, 42 , 354-364. [CrossRef]

18. Pothitou, M.; Hanna, R.F.; Chalvatzis, K.J. ICT entertainment appliances' impact on domestic electricity consumption. Renew. Sustain. Energy Rev. 2017, 69, 843-853. [CrossRef]

19. Ismail, H.; Hanafiah, M.M. An overview of LCA application in WEEE management: Current practices, progress and challenges. J. Clean Prod. 2019, 23220, 79-93. [CrossRef]

20. Darby, S.J. Smart technology in the home: Time for more clarity. Build Res. Inf. 2018, 46, 140-147. [CrossRef]

21. van Dam, S.S.; Bakker, C.A.; Buiter, J.C. Do home energy management systems make sense? Assessing their overall lifecycle impact. Energy Policy 2013, 63, 398-407. [CrossRef]

22. Louis, J.; Calo, A.; Leiviskä, K.; Pongrácz, E. Environmental impacts and benefits of smart home automation: Life cycle assessment of home energy management system. IFAC-PapersOnLine 2015, 48, 880-885. [CrossRef]

23. Beucker, S.; Bergesen, J.; Gibon, T. Building energy management systems. Global potentials and environmental implications of deployment. J. Ind. Ecol. 2016, 20, 223-233. [CrossRef]

24. Gangolells, M.; Casals, M.; Forcada, N.; Macarulla, M.; Giretti, A. Energy performance assessment of an intelligent energy management system. Renew. Sustain. Energy Rev. 2016, 55, 662-667. [CrossRef] 
25. Louis, J.; Pongrácz, E. Life cycle impact assessment of home energy management systems (HEMS) using dynamic emissions factors for electricity in Finland. Environ. Impact Assess. Rev. 2017, 67, 109-116. [CrossRef]

26. Scheepens, A.; Vogtländer, J. Insulation or smart temperature control for domestic heating: A combined analysis of the costs, the eco-costs, the customer perceived value, and the rebound effect of energy saving. Sustainability 2018, 10, 3231. [CrossRef]

27. Kern, E.; Dick, M.; Naumann, S.; Hiller, T. Impacts of software and its engineering on the carbon footprint of ICT. Environ. Impact Assess. Rev. 2018, 52, 53-61. [CrossRef]

28. EnerGAware Project. Energy Game for Awareness of Energy Efficiency in Social Housing Communities. 2015. EU Funded Project, Contract Number: 649673. Available online: http:/ / energaware.eu/ (accessed on 8 October 2020).

29. Morganti, L.; Pallavicini, F.; Cadel, E.; Candelieri, A.; Archetti, F.; Mantovani, F. Gaming for Earth: Serious games and gamification to engage consumers in pro-environmental behaviours for energy efficiency. Energy Res. Soc. Sci. 2017, 29, 95-102. [CrossRef]

30. Johnson, D.; Horton, E.; Mulcahy, R.; Foth, M. Gamification and serious games within the domain of domestic energy consumption: A systematic review. Renew. Sust. Energ. Rev. 2017, 73, 249-264. [CrossRef]

31. Pasini, D.; Reda, F.; Häkkinen, T. User engaging practices for energy saving in buildings: Critical review and new enhanced procedure. Energ. Build. 2017, 148, 74-88. [CrossRef]

32. AlSkaif, T.; Lampropoulos, I.; van den Broek, M.; van Sark, W. Gamification-based framework for engagement of residential customers in energy applications. Energy Res. Soc. Sci. 2018, 44, 187-195. [CrossRef]

33. Csoknyai, T.; Legardeur, J.; Akle, A.A.; Horváth, M. Analysis of energy consumption profiles in residential buildings and impact assessment of a serious game on occupants' behavior. Energ. Build. 2019, 196, 1-20. [CrossRef]

34. Himeur, Y.; Alsalemi, A.; Al-Kababji, A.; Bensaali, F.; Amira, A. Data fusion strategies for energy efficiency in buildings: Overview, challenges and novel orientations. Inf. Fusion. 2020, 64, 99-120. [CrossRef]

35. Chatzigeorgiou, I.M.; Andreou, G.T. A systematic review on feedback research for residential energy behavior change through mobile and web interfaces. Renew. Sustain. Energ. Rev. 2021, 135, 110187. [CrossRef]

36. Mulcahy, R.; Russell-Bennett, R.; Iacobucci, D. Designing gamified apps for sustainable consumption: A field study. J. Bus. Res. 2020, 106, 377-387. [CrossRef]

37. Anderson, B.; Rushby, T.; Bahaj, A.; James, P. Ensuring statistics have power: Guidance for designing, reporting and acting on electricity demand reduction and behaviour change programs. Energy Res. Soc. Sci. 2020, 59, 101260. [CrossRef]

38. Frederiks, E.R.; Stenner, K.; Hobman, E.; Fischle, M. Evaluating energy behavior change programs using randomized controlled trials: Best practice guidelines for policymakers. Energy Res. Soc. Sci. 2016, 22, 147-164. [CrossRef]

39. Casals, M.; Gangolells, M.; Macarulla, M.; Forcada, N.; Fuertes, A.; Hafner, R.; Jones, R. Assessing the effectiveness of gamification in reducing domestic energy consumption: Lessons learned from the EnerGAware project. Energy Build. 2020, $210,109753$. [CrossRef]

40. Energy Cat: The House of Tomorrow. 2017. Available online: http://www.energycatgame.com/ (accessed on 8 October 2020).

41. Casals, M.; Gangolells, M.; Macarulla, M.; Fuertes, A.; Jones, R.; Pahl, S.; Ruiz, M. Promoting energy users' behavioural change in social housing through a serious game. In ECPPM 2016 eWork and eBusiness in Architecture, Engineering and Construction: Proceedings of the 11th European Conference on Product and Process Modelling, Limassol, Cyprus, 7-9 September 2016; Christodoulou, S.E., Scherer, R., Eds.; CRC Press: London, UK, 2016; pp. 573-577.

42. Pré. SimaPro Database Manual. Methods Library. 2018. Available online: https://www.pre-sustainability.com/download/ DatabaseManualMethods.pdf (accessed on 22 October 2019).

43. International Standard Organization. Environmental Management-Life Cycle Assessment—Principles and Framework. ISO 14040. 2006. Available online: https:/ / www.iso.org/standard/37456.html (accessed on 18 March 2021).

44. International Standard Organization. Environmental Management—Life Cycle Assessment-Requirements and Guidelines. ISO 14044. 2006. Available online: https:/ / www.iso.org/standard/38498.html (accessed on 18 March 2021).

45. Swiss Centre for Life Cycle Inventories. Ecoinvent Database v3.4. Available online: http://www.ecoinvent.org/database/ (accessed on 8 October 2020).

46. Pascual-González, J.; Guillén-Gosálbez, G.; Mateo-Sanz, J.M.; Jiménez-Esteller, L. Statistical analysis of the ecoinvent database to uncover relationships between life cycle impact assessment metrics. J. Clean Prod. 2016, 112, 359-368. [CrossRef]

47. Pons, J.J.; Penadés-Plà, V.; Yepes, V.; Martí, J.V. Life cycle assessment of earth-retaining walls: An environmental comparison. J. Clean Prod. 2018, 192, 411-420. [CrossRef]

48. Pré. Simapro LCA software 8.0. 2017. Available online: http:/ / www.pre-sustainability.com/simapro (accessed on 29 November 2020).

49. EnerGAware project. Deliverable 4.3. Pilot Implementation Evaluation (Preliminary). 2017. Available online: http:/ / energaware. eu/downloads/EnerGAwareD4.3Pilot\%20implementation\%20evaluation\%20preliminaryr1.pdf (accessed on 16 October 2020).

50. EASME. Guidelines for the Calculation of Project Performance Indicators. 2017. Available online: https:/ / ec.europa.eu/easme/ sites / easme-site/files/guidelines-for-the-calculation-of-performance-indicators.pdf (accessed on 16 June 2020).

51. Building Research Establishment. CO2 and Primary Energy Factors for SAP 2016 Version 1.0. 2016. Available online: https: //www.bre.co.uk/filelibrary/SAP/2016/CONSP-07---CO2-and-PE-factors---V1_0.pdf (accessed on 29 November 2020).

52. Covenant of Mayors for Climate and Energy. The Covenant of Mayors for Climate and Energy Reporting Guidelines. 2016. Available online: http://www.covenantofmayors.eu/IMG/pdf/Reporting_Guidelines_Final_EN.pdf (accessed on 16 December 2020). 
53. Eurostat. Simplified Energy Balances-Annual Data. 2018. Available online: https://ec.europa.eu/eurostat/en/web/productsdatasets/-/NRG_100A (accessed on 28 June 2020).

54. European Commission. Proposal for a Directive of the European Parliament and of the Council Amending Directive 2012/27/EU on Energy Efficiency. 2016. Available online: https:/ / eur-lex.europa.eu/legal-content/EN/TXT/HTML/?uri=CELEX:52016PC0 $761 \&$ from $=E N$ (accessed on 16 June 2020).

55. European Environment Agency. Trends and Projections in Europe 2018. Tracking Progress towards Europe's Climate and Energy Targets. 2018. Available online: https:/ / www.eea.europa.eu//publications/trends-and-projections-in-europe-2018-climateand-energy (accessed on 29 January 2020). 